\title{
Advocacy and piloting the first needle and syringe exchange program in Iranian prisons
}

\author{
Mohammad Shahbazi ${ }^{*}$ Marziyeh Farnia, Mohammadreza Keramati, Ramin Alasvand \\ From $16^{\text {th }}$ International Symposium on HIV and Emerging Infectious Diseases \\ Marseille, France. 24-26 March 2010
}

\begin{abstract}
Background
1-Pilot the PNEP in the Iranian prisons after having received the acceptance of the authorities in the Iranian Judiciary System. 2-Schedule the piloting of the PNEP in the Iranian prisons. 3-Analyse the opinions given by the policy-makers in prisons and the staff to have a better implementation of the programme. (during pre-, while and post-stages) 4-Collect and evaluate demographic crime and drug data of the IDU's who are easily reached since in this program the IDU's can quite easily mention their difficulties with drugs. 5 - Distribute the sterile syringes among the IDU's without any limitations and evaluate the data based on the number of sterile received and used returned syringes respectively.
\end{abstract}

\section{Methods}

After recieving acceptance of policy-makers, program performed in 3 prisons and all the volunteers were IV drug abusers. The program had been performed in three major prison centers in Iran, including Tehran, Isfahan and Hamadan. The prisoners were given sterile needles and syringes weekly, and the used ones were also collected regularly. Data including number of syringes and shared ones used by each person was collected at the beginning of program; and this data was also documented on a weekly basis as the program proceeded. Information regarding blood-borne diseases was also given to the enrolled prisoners continuously.

\section{Results}

Among 341 volunteer prisoners enrolled in this program, an average of 17 syringes was reported to be used weekly for IV drug injection before starting the program. Moreover, the volunteers reported to use an average of 3.7 shared syringes during a week. Documented

\footnotetext{
* Correspondence: mohamad.shahbazi@yahoo.com Iran Prisons Organization, Tehran, Iran, Islamic Republic of
}

infection with blood-borne diseases (including Human Immunodefficiency Virus, Hepatitis B or C) was also found in 44 prisoners. At the end of the program, prevalence of using shared syringes among volunteers was decline to zero.

\section{Discussion}

1-Iran Prisons Organisations will be going to extend the programme to the rest of the Iranian prisons in case the results are satisfactory and there are minor complications.2-Voluntary entrance of the prisoners into the PNEP shows that despite the access to the other harm reduction programmes, the need and desire to inject drugs will not disappear and if the prisoners are not given sterile syringes and needles, they will share them. 3-Programming, process, problems and their solutions during the programme can be of great help to the rest of the Iranian prisons and other prisons worldwide. 4The average number of prisoners who entered the programme in the three target prisons has been between 25 and 35 per month and the volunteer prisoners have always intended to use syringes. 5-The average age of starting the injection has been 25 which simply shows a young majority which can help spread the diseases in the society more rapidly. And almost half of the mentioned prisoners are married and will act as a bridge to spread the disease in the society in a faster pace. 6-The other demographic characteristics of this group of IDU's including education, profession, etc. should be considered in harm reduction programmes planning. 7-The high frequency of drug-related crimes shows the necessity and importance of considering these prisoners in harm reduction programmes. 8-As mentions by the IDU's, they inject drugs three times a day and this figure can help in determining the number of needed syringes during syringe distribution. 9-A high proportion of prisoners have no laboratory records of HIV, HCV and 
HBV while this is the most high risk group and access to consulting services and laboratory tests must be made available for them. 10-The high proportion of prisoners with multiple partners has made this group very special in harm reduction programmes and if not properly controlled, they can be infected by HIV easily and the virus is then spread among the partners and later to the society. Syringe distribution among these prisoners can help reduce the problem.

Published: 11 May 2010

doi:10.1186/1742-4690-7-S1-P81

Cite this article as: Shahbazi et al:: Advocacy and piloting the first needle and syringe exchange program in Iranian prisons. Retrovirology 2010 7(Suppl 1):P81.
Submit your next manuscript to BioMed Central and take full advantage of:

- Convenient online submission

- Thorough peer review

- No space constraints or color figure charges

- Immediate publication on acceptance

- Inclusion in PubMed, CAS, Scopus and Google Scholar

- Research which is freely available for redistribution

Submit your manuscript at www.biomedcentral.com/submit 